\title{
The Mathematics Learning Media uses Geogebra on the Basic Material of Linear Equations
}

\author{
Qurnia Syafitri ${ }^{1}$, Mujib $^{2}$, Chairul Anwar ${ }^{3}$, Netriwati ${ }^{4}$, Wawan $^{5}$ \\ 1,2,3,4 Universitas Islam Negeri Raden Intan Lampung \\ ${ }^{5}$ Universitas Negeri Yogyakarta \\ 'Correspondence Address: qurnia.syafitri@gmail.com
}

\begin{abstract}
This research aims to develop a mathematical learning media using Geogebra software. The research method is used the 4D (Four D Model) research method adopted by Siva sailam Thiagarajan, Dorothy S. Semmel, and Melvyn I. Semmel. namely, define, design, develop. The data collection techniques are used to obtain the data on questionnaires response and interviews. The instruments in this research used questionnaires. The data analysis method using descriptive method. This research is conducted by describing the results of product development in the form of learning media for small groups and large groups with media that has been validated by some validators. The Experts of validation results on the content quality aspect to obtain results with very good criteria and on aspects of the language to obtain results with very good criteria. Trial students VII class in small classes and large classes obtained results with interesting criteria for small groups.
\end{abstract}

Keywords: Geogebra; Mathematical Media Development.

\section{INTRODUCTION}

Education means to the purpose of the growth and development of the nation. Education is also a long-term human resource investment that has strategic value for the continuity of human civilization in the world (Yuliasari, 2017). Therefore, the education becomes one of the important things to advance a nation because the welfare and progress of a nation can be seen from the level of education. Education takes an important role in creating quality individuals (Widyawati, 2017). It causes the world of education requires innovations in the progress of science and technology without ignoring the values of humanity. Education is also seen as a media to bring up of intelligent, creative, skilled, responsible, productive and respective people (Widyawati, 2017). One of education that can develop the ability and creativity is a mathematics education in which there is mathematical material (Anggoro, 2015).

The mathematical subject is one of the subjects that has great benefits in life. Mathematics gives students the opportunity to train they're minds and can affect their intellectual development. Through mathematical subject, students can learn to acquire the knowledge systematically (Ayda \& Widjajanti, 2014). One of the mathematical learning goals that learners can apply mathematics appropriately in their daily life as well as in various sciences, in order to prepare and improve the quality of human resources (Putra, Tastra, \& Suwatra, 2014; Son, 2016).

In the world of technology as well as in everyday life, the people often deal with numerical calculations. Almost everything in the world uses the mathematics. To realize good mathematics education, need to involve some problems to be solved, such as problems in the process of learning activities. The use of monotonous methods that can lead to the process of 
learning mathematics seems less creative (Masykur, Nofrizal, \& Syazali, 2017; Yulianti, Zulkardi, \& Siroj, 2010; Nugroho, Putra, Putra, \& Syazali, 2017)

Similarly, on SMP Negeri 23 Bandar Lampung, based on interviews was conducted with one of the mathematics teachers is obtained that the teaching materials are sufficient, but the learning media are used that inadequate for learners. Due to the lack of existing facilities in schools and the absence of teacher innovation in the making of learning media, so that learning in the class seems monotonous. In addition, the other data obtained from interviews and questionnaires were conducted with some students of VII and VIII class, from the results of the questionnaire can be concluded that they don't like mathematics because the lesson is full of formulas, teachers teach monotonous and media learning were used less interesting so that the student's motivation to study mathematics is still less, according to result of questionnaire was obtained of 30 learners, $13 \%$ or 4 learners wanted in mathematical learning of comics form, $30 \%$ or 9 students wanted collection illustrated formula, and 57\% or 17 students wanted a mathematics learning software, it is necessary to develop a learning media that makes learners do not feel bored by utilizing the existing technology in the present make it a solution in helping the process of material ignorance. Therefore, researchers are interested in developing learning media using GeoGebra in the mathematical learning of linear equations materials, with the media as a reference to facilitate the view of the material presented and also aims to minimize the learner's assumptions that mathematics is boring. After the researcher concluded of what kind of media is meant, Octhalia said that the media is good if the content is educated and used as a medium of learning. The media can be used to create visuals of mathematical tools as supporting materials for realistic mathematics education by utilizing information technology that can motivate learners to be interested in learning (Sudrajat \& Muslim, 2012).

Learning media is also an important factor in the learning because a media is an intermediary that can help the ongoing teaching and learning activities for both teachers and learners. Teachers are helpful in delivering the teaching material, and learners are helped because they can understand certain material using media because the effective teachers are very systematic in preparation, and implementation in their material. $t$ shows that learning activities will be effective if planned and managed well (Yuliyanto \& Jailani, 2014). The object of mathematics is abstract, so it requires a demonstration in learning it. So the media needed to guide the learning mathematics that is systematic and tend to be rigid. In addition, the mathematics learning that is carried out is still verbalist and teacher-centered (Sari, 2017). The Learning that seems conventional is not maximal in meeting the needs of students and they also feel boring. This is agreed in Abdussakir 's state that junior high level still many students have not understood the concepts of geometry. Therefore, it is necessary to have independent learning media which can make learning more interesting.

Briggs in sulistiyani etc, mentions that the media are all physical tools that can present the message and stimulate learners to learn (Sulistyani, Jam, \& Rahardjo, 2013). Meanwhile, Schramm argues that the media is an information technology or instructional message that can be manipulated, seen, heard and read (Abidin, Purnama, \& Nugroho, 2013). Judging from the function of the media in the process of teaching and learning, the use of media in learning resulted in new desires and interests, increasing motivation and stimulation of learning 
activities, and even psychologically affect of the learners (Sari, 2017). Therefore the researcher is interested to develop learning media in mathematics subject. Media will be developed using GeoGebra software.

GeoGebra is a dynamic geometry system software that can construct points, vectors, segments, lines, slices, cones, even functions and dynamically change them. In addition, with GeoGebra, the learners can draw and define equations and coordinates directly. GeoGebra also has the ability to connect variables with numbers, vectors and points, find derivatives and integrate functions as well as give commands to find extreme or root points. Additionally, the GeoGebra program allows simple visualization of complex geometric concepts and improve students' understanding of the concept (Supriadi, 2015). Therefore, the researcher is interested to develop the learning media of mathematics using GeoGebra to foster the interest and liveliness of learners in the learning of mathematics.

\section{THE RESEARCH METHODS}

The research uses research and development method, conducted in SMP Negeri 23 Bandar Lampung on November 22, 2017. The test of this product is done to 17 students for small-scale and 32 large scale students are taken in several classes simultaneously test to see learners' learning outcomes. According to Sugiyono in Masykur et al, Research and Development is a research method used to produce a current product and test the effectiveness of the product (Masykur et al., 2017). The research refers to 4D (Four D Model) research stages adopted by Sivasailam Thiagarajan, Dorothy S. Semmel, and Melvyn I. Semmel (Trianto, 2010). The implementation of research and development (R \& D), 4D Model consists of 4 general steps. The stages are:

\section{Defining}

Defining and establishing the terms of the development of animation media using GeoGebra to improve learners' learning outcomes is an objective to be achieved at this stage of the study.

\section{Designing}

This stage is done to design the media using GeoGebra to improve learners' learning outcomes.

\section{Developing}

This stage is done to produce the media using GeoGebra to improve the understanding of learners' concepts.

\section{Disseminating}

The last stage in this research is the disseminating stage. The dissemination stage is done to promote the development product in order to be accepted by users, whether individuals in groups or systems.

The technique are used in this study in collecting data using two types of data collected, namely: quantitative data and qualitative data. Data collection techniques used to obtain data on student responses on questionnaires and interviews. The instruments are used that has a total scoring score can be searched by using the formula as follows: 
Information:

$$
P=\frac{x}{y} \times 100 \%
$$

$\mathrm{P}=$ Percentage of Eligibility

$\mathrm{x}=$ Number of Scores $\mathrm{y}=$

Number of Ideal Scores

The quality of mathematics learning media obtained from student's answer of the assessment sheet by the experts and the response of the learners is contained in the form of the product feasibility table. Then the data are used as a basis for revision of instructional media that have been made. The assessment sheet that has been filled by the experts then analyzed to determine the quality of instructional media made by researchers.

Table 1. Experiment Validation Score Experts and learners' responses (modified)

\begin{tabular}{ll}
\hline Interval & Categories \\
\cline { 2 - 2 } $60 \%<\mathrm{P} \leq 80 \%$ & Very interesting \\
$40 \%<\mathrm{P} \leq 60 \%$ & Good \\
$20 \%<\mathrm{P} \leq 40 \%$ & Enough \\
$0 \% \leq \mathrm{P} \leq 20 \%$ & Less \\
\hline
\end{tabular}

Based on Table 1, the score of expert validation assessment and the learners' response toward the use of the product has an answer choice according to the question content. Each answer option has a different score that defines the level of product suitability for the consument. The results of the scoring scores of each material expert's validator, the media expert, and the learner's responses are searched average and converted to questions to determine the validity and feasibility of the learning media. Can be seen in Table 2:

Table 2 Criteria Validation Guidelines Score Assessment of Answer Options

\begin{tabular}{lc}
\hline Scoring Answer & Score \\
\hline Strongly Agree & 5 \\
Agree & 4 \\
Agree on Enough & 3 \\
Disagree & 2 \\
Strongly Disagree & 1 \\
\hline
\end{tabular}

Based on Table 2, the media that have been validated then viewed the criteria scores to determine the feasibility and attractiveness of the media. Using the similar steps, the researcher gets the response of learners that will be given after learning with the medium of learning mathematics using GeoGebra based on the questionnaire that has been given. 


\section{THE RESULTS OF THE RESEARCH AND THE DISCUSSION}

The results of this research and development is a media of learning mathematics. The stages are used in this research and development are 4D research and development methods. The stages are:

\section{Defining}

At this stage, the information is obtained that in the teaching-learning process are using instructional media that is teaching materials from paperboard. Especially for the linear equation, the teacher has not been used instructional media.

\section{Designing}

The Media that will be developed is the media using GeoGebra to improve students' learning outcomes in the basic subjects of linear equations. In the design stage, there are four steps that covering the preparation of early benchmark tests in the form of questionnaire preparation, media selection, format selection, preliminary design

\section{Developing}

On this stage, the media is created using the GeoGebra app. In addition at this stage, there is also a stage of expert validation and product feasibility tests. After the media are made then the assessment by the material and media experts. After being assessed this media is declared valid and feasible to use as a learning media. For validation results as follows.

The test of the product was conducted by small group trial tested on selected students of VIII class SMP Negeri 23 Bandar Lampung and large group test was tested to all students of VIII class SMP Negeri 23 Bandar Lampung. The validation was done by material experts and media experts.

\section{a. Material Expert Validation}

The Expert material validation results can be seen in the following table:

Tabel 3. The Result of Material Expert Validation

\begin{tabular}{lll}
\hline Average score & Criteria & Description \\
\hline $88 \%$ & Valid & No revision \\
\hline
\end{tabular}

Based on Table 3., it can be seen that the result of validation by the material expert reaches an average score of $88 \%$, the results are in accordance with valid criteria so that the media deserve to be used based on the material expert.

\section{b. The Media Expert's Validation}

The results of validation Scoring by media experts can be seen in the following table: Table 4. The Media Expert's Validation Results

\begin{tabular}{lll}
\hline Average Score & Criteria & Description \\
\hline $86,5 \%$ & Valid & No Revision \\
\hline
\end{tabular}

Based on Table 4., it can be seen that the results of validation by the media expert achieved an average score of $86.5 \%$, the results are valid criteria so that the media feasible to use based on The media expert. 


\section{Trials}

Validation by the experts then carried out the trial stage of media attractiveness. The results of the experiment related to attractiveness are conducted through two years are small group test and field test has increased the average score on the aspect, the Comparison of test results can also be seen in the picture below:

Tabel 5 Small Group Trial Result

\begin{tabular}{clcc}
\hline Response & Score Result & Feasibility percentage Score & Criteria \\
\hline 1 & 38 & 84.44 & SL \\
2 & 38 & 84.44 & SL \\
3 & 39 & 86.66 & SL \\
4 & 39 & 86.66 & SL \\
5 & 40 & 88.88 & SL \\
6 & 39 & 86.66 & SL \\
7 & 41 & 91.11 & SL \\
8 & 40 & 88.88 & SL \\
9 & 36 & 80 & SL \\
10 & 40 & 88.88 & SL \\
11 & 43 & 95.55 & SL \\
12 & 37 & 82.22 & SL \\
13 & 42 & 93.33 & SL \\
14 & 37 & 82.22 & SL \\
15 & 37 & 82.22 & SL \\
16 & 27 & 60 & L \\
17 & 45 & 100 & SL \\
Result & 658 & 1462,15 & $=86$ \\
\hline
\end{tabular}

Tabel 5 Large Group Trial Result

\begin{tabular}{llll}
\hline Response & Score Result & Feasibility Score & Criteria \\
\hline 1 & 37 & 82,22 & SL \\
2 & 38 & 84,44 & SL \\
3 & 38 & 84,44 & SL \\
4 & 39 & 86,66 & SL \\
5 & 43 & 95,55 & SL \\
6 & 45 & 100 & SL \\
7 & 38 & 84,44 & SL \\
8 & 40 & 88,88 & SL \\
9 & 36 & 80 & SL
\end{tabular}




\begin{tabular}{llll}
\hline 10 & 36 & 80 & $\mathrm{SL}$ \\
11 & 38 & 84,44 & $\mathrm{SL}$ \\
12 & 37 & 82,22 & $\mathrm{SL}$ \\
13 & 40 & 88,88 & $\mathrm{SL}$ \\
14 & 38 & 84,44 & $\mathrm{SL}$ \\
15 & 41 & 91,11 & $\mathrm{SL}$ \\
16 & 40 & 88,88 & $\mathrm{SL}$ \\
17 & 37 & 82,22 & $\mathrm{SL}$ \\
18 & 37 & 82,22 & $\mathrm{SL}$ \\
19 & 40 & 88,88 & $\mathrm{SL}$ \\
20 & 40 & 88,88 & $\mathrm{SL}$ \\
21 & 36 & 80 & $\mathrm{SL}$ \\
22 & 37 & 82,22 & $\mathrm{SL}$ \\
23 & 43 & 95,55 & $\mathrm{SL}$ \\
24 & 42 & 93,33 & $\mathrm{SL}$ \\
25 & 41 & 91,11 & $\mathrm{SL}$ \\
26 & 40 & 88,88 & $\mathrm{SL}$ \\
27 & 41 & 91,11 & $\mathrm{SL}$ \\
28 & 41 & 91,11 & $\mathrm{SL}$ \\
29 & 41 & 91,11 & $\mathrm{SL}$ \\
30 & 40 & 88,88 & $\mathrm{SL}$ \\
31 & 41 & 91,11 & $\mathrm{SL}$ \\
31 & 41 & 91,11 & $\mathrm{SL}$ \\
Total & 1262 & 2713,21 & $\overline{\mathrm{X}}$ \\
& & &
\end{tabular}

After small group trials and large group trials to determine the feasibility of learning media using GeoGebra on linear equations, the product is said to be strongly feasible. Furthermore, the media can be utilized as one of the learning media for students and teachers in the junior high school on the linear equations for class VIII.

The media that has been produced is followed up as a comparison, so here the researchers do the test of the linear equation through several cycles. The first cycle is done before the media applied in the learning results obtained as follows:

Tabel 6. The Percentage of Learning Outcomes in Mathematics Subject of Cycle I Observation at Class VIII Students 2017/2018

\begin{tabular}{lcll}
\hline No & Description & Total & Percentage \\
\hline 1 & The Student Complete & 21 & $65,625 \%$ \\
\hline 2 & The Student has not completed yet & 11 & $34,375 \%$ \\
\hline 3 & The Total of Students & 32 & $100 \%$ \\
\hline
\end{tabular}

The Percentage mastery students' learning result is be obtained by the formula: 
The Percentage $=\frac{\sum \text { Student Complete }}{\sum \text { The Total of Students }} \times 100 \%$

$$
=\frac{21}{32} \times 100 \%=65,625 \%
$$

Based on Table 6, it can be seen that in cycle I, there are 21 students, which is $65,625 \%$ with 21 students complete while there are 11 students who still have obstacles in learning.

The result of action in cycle I have not succeeded, the students' success is determined by learners reaching $\geq 80 \%$ of students in the class. Therefore, it is necessary to improve learning in the next cycle $t$ the to improve students' learning outcomes and can achieve the indicator. Furthermore, the researcher has applied the result of learning media of mathematics using GeoGebra, the researcher has conducted the resulting test by reviewing the practice and direct comprehension to the students about the linear equation material in a different way from cycle I then got the result of learning in cycle II following:

Table 7. The Learning Outcomes Percentage in Mathematics Subject of Cycle II Observation in The Student of VIII Class 2017/2018

\begin{tabular}{lcll}
\hline No & Description & Total & Percentage \\
\hline 1 & The Students Complete & 31 & $96,875 \%$ \\
\hline 2 & The students have not completed & 1 & $3,125 \%$ \\
\hline 3 & The Total of Student & 36 & $100 \%$ \\
\hline
\end{tabular}

The mastery learning outcomes Percentage of TheStudents are classically obtained by the formula:

$$
\begin{aligned}
\text { Persentase }= & \frac{\sum \text { The Student Complete }}{\sum \text { The total Of Students }} \times 100 \% \\
& =\frac{31}{32} \times 100 \%=96,875 \%
\end{aligned}
$$

Based on Table 7, it can be seen in cycle II The students who complete total are 31 students. Thus the learning outcomes of students cycle II has increased after using the media learning mathematics Geogebra, that increased to $96.875 \%$ with the total of students 31 people, while previously only reached $65.625 \%$ with the total of students, 21 people. The students who are not complete in cycle II as much as 1 person with percentage $3.125 \%$. The following is a table of data on improvement of learning outcomes of learners from cycle I and cycle II:

Table 8. the Data Improvement of Learning Outcomes in Mathematics Subject in VIII Class

\begin{tabular}{llrr}
\hline \multirow{2}{*}{ Data } & Criteria & $\begin{array}{l}\text { The Achieving } \\
\text { on KKM }\end{array}$ & $\begin{array}{c}\text { Percentage The } \\
\text { Students Achieving on KKM }\end{array}$ \\
\hline \multirow{2}{*}{ Cycle I } & Complete & $65,625 \%$ & 21 \\
\cline { 2 - 4 } & Not Complete & $34,375 \%$ & 11 \\
\hline \multirow{2}{*}{ Cycle II } & Complete & $96,875 \%$ & 31 \\
\cline { 2 - 4 } & Not Complate & $3,125 \%$ & 1 \\
\hline Total & & $31,125 \%$ & 10
\end{tabular}

Source: The Learning Outcome of Students Cycle I and II at VIII Class / SMP Negeri 23 Bandar Lampung 
From the data in Table 8, it can be seen that the increasing of cycle I to cycle II were increased by $31.125 \%$ with the Total of 10 students, as for the details of the percentage of students who completed in the second cycle is $96.875 \%$ with the total of 31 students were compared with a cycle I of $65.625 \%$ with the total of 21 students.

\section{Disseminating Stage}

Before this stage, there is a revision of the product performed to find the product problem during the product trial. However, in this research, there were no obstacles in the product trial so no revision was needed. The last stage of research and development is the disseminating stage.

\section{CONCLUSIONS AND SUGGESTIONS}

The product was obtained from the research and development is the media of mathematics learning using GeoGebra on linear equations which were developed by 4D model. The result of feasibility test learning media through revision and validation stage then media and material validator with the result stated learning media using GeoGebra which has been developed and feasible to be used as learning media. The Response of student and teacher toward the feasibility of learning media was obtained the average score of $87.63 \%$ and $93 \%$ with strongly feasible criteria. Student responses applied through the cycle I and cycle II test showed that the increase of the cycle I to cycle II was increased by $31.125 \%$. The Improvement of students learning outcomes before and after the media applied of teaching media using GeoGebra with the percentage of students who completed in the second cycle is $96.875 \%$ with the total of 31 Students were compared to the first cycle of $65.625 \%$ with the total of 21 students. So it can be concluded that the media used GeoGebra on linear equations material can improve and feasible for the students. The Media can be used by the teacher to support the learning process in the classroom. For further research, it is also permissible to test the effectiveness of the use of GeoGebra software.

\section{REFERENCES}

Abidin, M. M., Purnama, B. E., \& Nugroho, G. K. (2013). Pembangunan Media Pembelajaran Teknik Komputer Jaringan Kelas X Semster Ganjil Pada Sekolah Menengah Kejuruan Taruna Bangsa Pati Berbasis Multimedia Interaktif. IJNS-Indonesian Journal on Networking and Security, 4(3).

Anggoro, B. S. (2015). Pengembangan Modul Matematika Dengan Strategi Problem Solvin Guntuk Mengukur Tingkat Kemampuan Berpikir Kreatif Matematis Siswa. Al-Jabar: Jurnal Pendidikan Matematika, 6(2), 121-130.

Ayda, E., \& Widjajanti, D. B. (2014). Pengembangan perangkat pembelajaran teorema pythagoras dengan media berbantuan komputer. Jurnal Riset Pendidikan Matematika, $1(2), 216-226$.

Masykur, R., Nofrizal, N., \& Syazali, M. (2017). Pengembangan Media Pembelajaran Matematika dengan Macromedia Flash. Al-Jabar : Jurnal Pendidikan Matematika, 8(2), 177-186. 
Nugroho, A. A., Putra, R. W. Y., Putra, F. G., \& Syazali, M. (2017). Pengembangan Blog Sebagai Media Pembelajaran Matematika. Al-Jabar: Jurnal Pendidikan Matematika, $8(2), 197-204$.

Putra, F. G. (2016). Pengaruh Model Pembelajaran Reflektif dengan Pendekatan Matematika Realistik Bernuansa Keislaman terhadap Kemampuan Komunikasi Matematis. AlJabar : Jurnal Pendidikan Matematika, 7(2), 203-210.

Putra, I. G. L. A. K., Tastra, I. D. K., \& Suwatra, I. I. W. (2014). Pengembangan Media Video Pembelajaran dengan Model Addie pada Pembelajaran Bahasa Inggrisdi SDN 1 Selat. Jurnal EDUTECH Undiksha, 2(1).

Sari, A. W. (2017). Pengembangan Media Pembelajaran berbantuan Web dengan Pendekatan Etnomatematika pada Pokok Bahasan Bangun Ruang Sisi Datar (PhD Thesis). UIN Raden Intan Lampung.

Sudrajat, D., \& Muslim, T. (2012). Perancangan Aplikasi Game Aritmatika Pada Handphone untuk Melatih Kemampuan Berhitung Kelas 1 dan 2 Sekolah Dasar Negeri II Ciperna Kabupaten. JURNAL ICT, 7(1).

Sulistyani, N. H. D., Jam, J., \& Rahardjo, D. T. (2013). Perbedaan hasil belajar siswa antara menggunakan media pocket book dan tanpa pocket book pada materi kinematika gerak melingkar kelas X. Jurnal Pendidikan Fisika, 1(1).

Supriadi, N. (2015). Pembelajaran Geometri Berbasis Geogebra Sebagai Upaya Meningkatkan Kemampuan Komunikasi Matematis Siswa Madrasah Tsanawiyah (MTs). Al-Jabar: Jurnal Pendidikan Matematika, 6(2), 99-110.

Trianto, M. P. (2010). Model pembelajaran terpadu: Konsep, strategi, dan implementasinya dalam Kurikulum Tingkat Satuan Pendidikan (KTSP). Kuala Lumpur: Kemetrian Pengajaran Malaysia.

Widyawati, S. (2017). Pengaruh Kemampuan Koneksi Matematis Siswa Terhadap Prestasi Belajar Matematika Ditinjau Dari Gaya Belajar Pada Materi Bangun Ruang Sisi Datar Siswa Kelas IX SMP di Kota Metro. Iqra': Jurnal Kajian Ilmu Pendidikan, 1(1), 47 68.

Yulianti, E., Zulkardi, Z., \& Siroj, R. A. (2010). Pengembangan Alat Peraga Menggunakan Rangkaian Listrik Seri-Paralel untuk Mengajarkan Logika Matematika di SMK Negeri 2 Palembang. Jurnal Pendidikan Matematika, 4(1), 25-32.

Yuliasari, E. (2017). Eksperimentasi Model PBL dan Model GDL terhadap Kemampuan Pemecahan Masalah Matematis ditinjau dari Kemandirian Belajar. JIPM (Jurnal Ilmiah Pendidikan Matematika), 6(1), 1-10.

Yuliyanto, Y., \& Jailani, J. (2014). Pengembangan perangkat pembelajaran geometri SMP menggunakan metode penemuan terbimbing pada kelas VIII Semester II. Jurnal Riset Pendidikan Matematika, 1(1), 127-138. 